\title{
DISKURSUS KOMPETENSI ABSOLUT PENGADILAN TATA USAHA NEGARA DALAM MENGADILI PERBUATAN PEMERINTAH DALAM PENGADAAN BARANG/JASA
}

(Discourses on Absolute Competence of the Administrative Court in Judging Government Action in Procurement)

\author{
Dian Agung Wicaksono \\ Dosen Departemen Hukum Tata Negara, Fakultas Hukum Universitas Gadjah Mada \\ email: dianagung@ugm.ac.id
}

Dedy Kurniawan

Hakim PTUN Surabaya, Jawa Timur

e-mail: koerniawanddy@gmail.com

\section{Bimo Fajar Hantoro}

Mahasiswa konsentrasi Hukum Tata Negara, Fakultas Hukum Universitas Gadjah Mada e-mail: bimo.f@mail.ugm.ac.id

Naskah diterima: 27 Agustus 2020; revisi: 7 November 2020; disetujui: 11 November 2020

\begin{abstract}
Abstrak
Diskursus mengenai kompetensi absolut Pengadilan Tata Usaha Negara (PTUN) dalam mengadili perbuatan pemerintah dalam pengadaan barang/jasa menjadi yang tidak pernah tuntas, karena dalam praktik PTUN di Indonesia ditemukan pandangan yang diametral dalam memaknai kompetensi absolut PTUN dalam memutus perkara terkait perbuatan pemerintah dalam pengadaan barang/jasa. Penelitian ini mencoba menjawab: (a) bagaimana konstruksi hukum dari kompetensi absolut pengadilan tata usaha negara di Indonesia (b) bagaimana dikotomi perbuatan pemerintah dalam pengadaan barang/jasa (c) bagaimana kompetensi absolut pengadilan tata usaha negara untuk mengadili perbuatan pemerintah dalam pengadaan barang/jasa. Penelitian ini menggunakan metode yuridis normatif, dengan menganalisis data sekunder berupa peraturan perundang-undangan dan pustaka yang terkait dengan kompetensi absolut peradilan tata usaha negara, administrasi pemerintahan, dan hukum pengadaan barang/jasa di Indonesia. Hasil dari penelitian ini menunjukkan bahwa keterbatasan pengaturan dalam UU Peratun 1986 dan perubahan membuat hakim memilih penafsiran ekstensif yang notabene kontradiktif dengan penafsiran gramatikal dari ketentuan UU Peratun 1986 dan perubahannya. Adapun seharusnya KTUN yang dikualifikasikan sebagai perbuatan hukum perdata adalah KTUN yang didasarkan pada perbuatan hukum perdata.
\end{abstract}

Kata Kunci: kompetensi absolut, peradilan tata usaha negara, perbuatan pemerintah, pengadaan barang/jasa

\begin{abstract}
The discourse on the absolute competence of the Administrative Court in adjudicating government actions in the procurement has never been completed because in the practice of Administrative Court, there is a diametric view of interpreting the Administrative Court's absolute competence in deciding cases related to government actions in procurement. This research tries to answer: (a) how is the legal construction of the absolute competence of the Administrative Court in Indonesia (b) what is the dichotomy of government actions in the procurement (c) what is the absolute competence of the Administrative Court to adjudicate government actions in the procurement. This is normative legal research that used secondary data in the form of statutory regulations and literature related to the absolute competence of the Administrative Court, government administration, and the law of procurement in Indonesia. The results of this study indicate that the limitations of the regulation in the 1986 Administrative Court Act and the amendments made the judge choose an extensive interpretation which incidentally contradictive the grammatical interpretation of the provisions of the 1986 Administrative Court Act and its amendments. As for administrative decisions that should be qualified as civil legal actions are state administrative decisions that are based on civil legal actions.

Keywords: absolut competence, administrative court, government action, procurement.
\end{abstract}




\section{A. Pendahuluan}

Diskursus mengenai kompetensi absolut Pengadilan Tata Usaha Negara (PTUN) dalam mengadili perbuatan pemerintah dalam pengadaan barang/jasa bukanlah isu yang benar-benar baru untuk dianalisis. Hal ini menjadi diskursus yang berkepanjangan karena memang dalam praktik PTUN di Indonesia ditemukan pandangan yang diametral dalam memaknai kompetensi absolut PTUN dalam memutus perkara terkait perbuatan pemerintah dalam pengadaan barang/jasa. ${ }^{1}$ Dua contoh kasus yang menggambarkan pandangan diametral tersebut adalah Putusan Mahkamah Agung Nomor 252 K/TUN/2000 dan Putusan Mahkamah Agung Nomor 557K/TUN/2014. Di satu sisi Putusan Mahkamah Agung Nomor 252 K/TUN/2000 memaknai ketentuan Pasal 2 huruf a UU Peratun secara ekstensif sehingga sangat membatasi kompetensi Peradilan TUN di bidang pengadaan barang/jasa. ${ }^{2}$ Di sisi lain, pada Putusan Mahkamah Agung Nomor 557K/TUN/2014 justru memaknai ketentuan Pasal 2 huruf a secara lebih limitatif dengan mengkualifikasikan KTUN yang lahir dengan didasarkan pada perbuatan hukum perdata sebagai KTUN yang merupakan perbuatan hukum perdata, sehingga kemudian Peradilan TUN memiliki kompetensi absolut yang lebih luas dalam memutus sengketa TUN di bidang pengadaan barang/jasa. ${ }^{3}$

Penelitian ini mencoba memberikan perspektif yang lain dalam melihat diskursus tersebut dengan terlebih dahulu melihat kompatibilitas dan dikotomi perbuatan pemerintah dalam pengadaan barang/jasa dengan kompetensi absolut yang dimiliki oleh PTUN. Berdasarkan latar belakang tersebut, penelitian ini berfokus pada permasalahan: (a) bagaimana konstruksi hukum dari kompetensi absolut pengadilan tata usaha negara di Indonesia? (b) bagaimana dikotomi perbuatan pemerintah dalam pengadaan barang/jasa? (c) bagaimana kompetensi absolut pengadilan tata usaha negara untuk mengadili perbuatan pemerintah dalam pengadaan barang/jasa?

\section{B. Metode Penelitian}

Penelitian ini merupakan penelitian yuridis normatif, ${ }^{4}$ dengan menggunakan bahan pustaka, yang terdiri dari 2 (dua) bahan hukum yaitu: (a) bahan hukum primer yang terdiri dari norma dasar atau kaidah, ketentuan atau peraturan dasar, serta peraturan perundangundangan; dan (b) bahan hukum sekunder adalah bahan hukum yang memberikan penjelasan lebih lanjut dari bahan hukum primer berupa literatur, artikel jurnal, dan juga hasil penelitian yang relevan. ${ }^{5}$ Pengambilan

1 Terdapat perbedaan penerapan hukum terhadap produk hukum yang timbul dalam pengadaan barang/jasa. Khusus berkenaan dengan pemenanglelang, secara umum terdapat 2 pendapat, yakni: (a) merupakan kewenangan absolut PTUN dengan pertimbangan perkembangan hukum administrasi; dan (b) bukan kewenangan PTUN yang berkaitan dengan teori oplossing maupun upaya administratif. Lihat dalam Febby Fajrurrahman, "Penerapan Hukum Pengadaan Barang/Jasa Pemerintah sebagai Sengketa Tata Usaha Negara", Jurnal Hukum Peratun, Vol. 2, No. 2 (2019): 216-217. Lihat juga Maftuh Effendi, "Peradilan Tata Usaha Negara Indonesia Suatu Pemikiran ke Arah Perluasan Kompetensi Pasca Amandemen Kedua Undang-Undang Peradilan Tata Usaha Negara", Jurnal Hukum dan Peradilan, Vol. 3, No. 1 (2014): 31.

2 Putusan Mahkamah Agung Nomor 252K/TUN/2000, tertanggal 13 November 2000.

3 Putusan Mahkamah Agung Nomor 557K/TUN/2014, tertanggal 6 Oktober 2014.

4 Soedjono Soekanto dan Sri Mamudji, Penelitian Hukum Normatif: Suatu Tinjauan Singkat Jakarta: Raja Grafindo Persada, 1994), hlm. 13.

5 Soerdjono Soekanto, Pengantar Penelitian Hukum (Jakarta: UI Press, 1986), hlm. 132. 
data dilakukan dengan studi pustaka terhadap buku, artikel, hasil penelitian, dan peraturan perundang-undangan yang relevan. Analisis data dilakukan secara deskriptif kualitatif untuk menjawab rumusan masalah dalam penelitian ini.

\section{Pembahasan}

\section{Konstruksi Hukum Kompetensi Absolut Pengadilan Tata Usaha Negara}

Dalam hukum acara, kewenangan pengadilan untuk memeriksa dan mengadili suatu perkara dibedakan menjadi dua, yaitu kompetensi absolut yang diartikan sebagai kewenangan pengadilan untuk mengadili berdasarkan objek atau materi atau pokok sengketanya, sedangkan kompetensi relatif merupakan kewenangan pengadilan untuk mengadili suatu perkara sesuai wilayah hukumnya. ${ }^{6}$ Spesifik terkait kompetensi absolut peradilan tata usaha negara, dalam Undang-Undang Nomor 5 Tahun 1986 tentang Peradilan Tata Usaha Negara (UU Peratun 1986) diatur bahwa Pengadilan bertugas dan berwenang memeriksa, memutus, dan menyelesaikan sengketa Tata Usaha Negara. ${ }^{7}$

Rumusan Pasal a quo menunjukkan bahwa kompetensi absolut PTUN disandarkan pada adanya sengketa Tata Usaha Negara. Adapun mengenai pendefinisian sengketa tata usaha negara adalah sengketa yang timbul dalam bidang tata usaha negara antara orang atau badan hukum perdata dengan badan atau pejabat tata usaha negara, baik di pusat maupun di daerah, sebagai akibat dikeluarkannya keputusan tata usaha negara, termasuk sengketa kepegawaian berdasarkan peraturan perundang-undangan yang berlaku. ${ }^{8}$ Keberadaan Keputusan Tata Usaha Negara (KTUN) menjadi aspek vital dalam kompetensi absolut PTUN, karena dapat dikatakan sengketa TUN lahir karena adanya suatu KTUN. ${ }^{9}$

Dinamika pengaturan mengenai KTUN menjadi poin penting untuk dicermati karena meluas atau menyempitnya kompetensi absolut PTUN disandarkan pada ruang lingkup dari KTUN. Dalam perkembangan pengaturan mengenai KTUN, selain dalam UU Peratun 1986 dan perubahannya, UU Nomor 30 Tahun 2014 tentang Administrasi Pemerintahan (UU Adpem) juga memberikan dinamika terkait ruang lingkup dari KTUN. Perbandingan pengaturan mengenai KTUN dalam hukum positif di Indonesia disajikan dalam Tabel 1 pada halaman 370.

Berdasarkan pengaturan dalam UU Adpem, dengan merujuk pada asas lex posteriori derogat legi priori, maka mutatis mutandis ketentuan mengenai KTUN dalam UU Peratun 1986 dan perubahannya dapat dikesampingkan keberlakuannya dengan rumusan dalam UU Adpem. Walaupun perumusan KTUN dalam UU Adpem dituangkan dalam Bab Ketentuan Peralihan

6 S.F. Marbun, Peradilan Administrasi Negara dan Upaya Administratif di Indonesia (Yogyakarta: UII Press, 2011), hlm. 239.

Pasal 47 Undang-Undang Nomor 5 Tahun 1986 tentang Peradilan Tata Usaha Negara.

Pasal 1 angka 10 Undang-Undang Nomor 51 Tahun 2009 tentang Perubahan Kedua Atas Undang-Undang Nomor 5 Tahun 1986 tentang Peradilan Tata Usaha Negara.

9 Philipus M. Hadjon, et al., Pengantar Hukum Administrasi Indonesia, (Yogyakarta: Gadjah Mada University Press, 2015), hlm. 309. 
Tabel 1. Dinamika Pengaturan Keputusan Tata Usaha Negara

\begin{tabular}{|c|c|}
\hline $\begin{array}{l}\text { UU Peratun } 1986 \text { dan } \\
\text { perubahannya }^{10}\end{array}$ & UU Adpem ${ }^{11}$ \\
\hline $\begin{array}{l}\text { Keputusan Tata Usaha } \\
\text { Negara adalah suatu } \\
\text { penetapan tertulis yang } \\
\text { dikeluarkan oleh Badan } \\
\text { atau Pejabat Tata Usaha } \\
\text { Negara yang berisi } \\
\text { tindakan hukum Tata Usaha } \\
\text { Negara yang berdasarkan } \\
\text { peraturan perundang- } \\
\text { undangan yang berlaku, } \\
\text { yang bersifat konkret, } \\
\text { individual, dan final, yang } \\
\text { menimbulkan akibat hukum } \\
\text { bagi seseorang atau badan } \\
\text { hukum perdata. }\end{array}$ & $\begin{array}{l}\text { Keputusan Administrasi Pemerintahan yang juga disebut Keputusan Tata } \\
\text { Usaha Negara atau Keputusan Administrasi Negara yang selanjutnya disebut } \\
\text { Keputusan adalah ketetapan tertulis yang dikeluarkan oleh Badan dan/atau } \\
\text { Pejabat Pemerintahan dalam penyelenggaraan pemerintahan. } \\
\text { Dengan berlakunya Undang-Undang ini, Keputusan Tata Usaha Negara } \\
\text { sebagaimana dimaksud dalam Undang-Undang Nomor } 5 \text { Tahun } 1986 \text { tentang } \\
\text { Peradilan Tata Usaha Negara sebagaimana telah diubah dengan Undang- } \\
\text { Undang Nomor } 9 \text { Tahun } 2004 \text { dan Undang-Undang Nomor } 51 \text { Tahun } 2009 \\
\text { harus dimaknai sebagai: } \\
\text { a. penetapan tertulis yang juga mencakup tindakan faktual; } \\
\text { b. Keputusan Badan dan/atau Pejabat Tata Usaha Negara di lingkungan } \\
\text { eksekutif, legislatif, yudikatif, dan penyelenggara negara lainnya; } \\
\text { c. berdasarkan ketentuan perundang-undangan dan AUPB; } \\
\text { d. bersifat final dalam arti lebih luas; } \\
\text { e. Keputusan yang berpotensi menimbulkan akibat hukum; dan/atau } \\
\text { f. Keputusan yang berlaku bagi Warga Masyarakat. }\end{array}$ \\
\hline
\end{tabular}

Sumber: Diolah Penulis, 2020.

menimbulkan diskursus ${ }^{12}$, namun menurut Penulis hal tersebut tidak mengurangi kekuatan hukum mengikat dari norma a quo dengan mendasarkan pada asas presumptio iustae causa.

Walaupun memang terdapat perbedaan pandangan dalam memaknai keberadaan rumusan Pasal 87 UU Adpem, karena di satu sisi dinilai bertentangan dengan ketentuan bahwa rumusan dalam Ketentuan Peralihan tidak memuat perubahan terselubung atas ketentuan Peraturan Perundang-undangan lain, karena perubahan inihendaknyadilakukan dengan membuat batasan pengertian baru di dalam Ketentuan Umum Peraturan Perundang-undangan atau dilakukan dengan membuat Peraturan Perundang-undangan perubahan. ${ }^{13}$ Namun demikian, di sisi yang lain Ketentuan Peralihan memang digunakan untuk memuat penyesuaian pengaturan

10 Pasal 1 angka 9 Undang-Undang Nomor 51 Tahun 2009 tentang Perubahan Kedua Atas Undang-Undang Nomor 5 Tahun 1986 tentang Peradilan Tata Usaha Negara.

11 Pasal 1 angka 7 dan Pasal 87 Undang-Undang Nomor 30 Tahun 2014 tentang Administrasi Pemerintahan.

12 Peletakan kriteria rinci Keputusan Tata Usaha Negara dalam Ketentuan Peralihan UU Adpem dikritik karena substansinya yang sangat pokok sehingga seharusnya diletakkan ke dalam pasal inti, bahkan dinilai karena telah memuat perubahan secara terselubung. Lihat Yodi Martono Wahyunadi, "Disertasi Kompetensi Absolut Pengadilan Tata Usaha Negara dalam Konteks Undang-Undang Nomor 30 Tahun 2014 tentang Administrasi Pemerintahan", Jurnal Hukum dan Peradilan, Vol. 5, No. 1 (2016): 147. Lihat juga Ridwan H.R., Despan Heyansyah, dan Dian Kus Pratiwi, "Perluasan Kompetensi Absolut Pengadilan Tata Usaha Negara dalam Undang-Undang Administrasi Pemerintahan", Jurnal Hukum Ius Quia Iustum, Vol. 25, No. 2 (2018): 342.

13 Lampiran II Angka 135 Undang-Undang Nomor 11 Tahun 2012 tentang Pembentukan Peraturan Perundangundangan. 
tindakan hukum atau hubungan hukum yang sudah ada berdasarkan Peraturan Perundangundangan yang lama terhadap Peraturan Perundang-undangan yang baru, yang bertujuan untuk: (a) menghindari terjadinya terhadap perluasan kompetensi absolut yang melekat pada PTUN. Bila lebih lanjut diurai unsur-unsur dari KTUN antara UU Peratun 1986 dan perubahannya dengan UU Adpem, didapatkan dikotomi sebagai berikut:

Tabel 2. Unsur Keputusan Tata Usaha Negara dalam UU Peratun dan UU Adpem

\begin{tabular}{|c|c|c|}
\hline Unsur & $\begin{array}{l}\text { UU Peratun } 1986 \text { dan } \\
\text { perubahannya }\end{array}$ & UU Adpem \\
\hline Bentuk & penetapan tertulis & $\begin{array}{l}\text { penetapan tertulis yang juga mencakup } \\
\text { tindakan faktual }\end{array}$ \\
\hline Pihak yang Mengeluarkan & $\begin{array}{l}\text { Badan atau Pejabat Tata Usaha } \\
\text { Negara adalah badan atau pejabat } \\
\text { yang melaksanakan urusan } \\
\text { pemerintahan berdasarkan } \\
\text { peraturan perundang-undangan } \\
\text { yang berlaku }\end{array}$ & $\begin{array}{l}\text { Badan atau Pejabat Tata Usaha Negara di } \\
\text { lingkungan eksekutif, legislatif, yudikatif, } \\
\text { dan penyelenggara negara lainnya dalam } \\
\text { penyelenggaraan pemerintahan }\end{array}$ \\
\hline Dasar & $\begin{array}{l}\text { berdasarkan peraturan perundang- } \\
\text { undangan }\end{array}$ & $\begin{array}{l}\text { berdasarkan ketentuan peraturan } \\
\text { perundang-undangan dan AUPB }\end{array}$ \\
\hline Sifat & $\begin{array}{l}\text { konkret, individual, dan final, yang } \\
\text { menimbulkan akibat hukum }\end{array}$ & $\begin{array}{l}\text { final dalam arti lebih luas, yang berpotensi } \\
\text { menimbulkan akibat hukum }\end{array}$ \\
\hline Adressat & $\begin{array}{l}\text { seseorang atau badan hukum } \\
\text { perdata }\end{array}$ & $\begin{array}{l}\text { Warga Masyarakat, yaitu seseorang atau } \\
\text { badan hukum perdata yang terkait dengan } \\
\text { Keputusan dan/atau Tindakan }\end{array}$ \\
\hline
\end{tabular}

Sumber: Diolah Penulis, 2020.

kekosongan hukum; (b) menjamin kepastian hukum; (c) memberikan perlindungan hukum bagi pihak yang terkena dampak perubahan ketentuan Peraturan Perundang-undangan; dan (d) mengatur hal-hal yang bersifat transisional atau bersifat sementara. ${ }^{14}$

Terlepas dari diskursus di atas, dinamika pengaturan KTUN telah membawa implikasi
Berdasarkan tabel di atas, terdapat beberapa catatan yang perlu untuk dicermati lebih lanjut, yaitu: Pertama, KTUN tidak lagi terbatas pada penetapan tertulis, tetapi mencakup pula tindakan faktual. Tindakan faktual atau feitelijk handeling dibedakan dengan rechtshandeling van de administratie $^{15}$ dan didefinisikan sebagai

14 Lampiran II Angka 127 Undang-Undang Nomor 11 Tahun 2012 tentang Pembentukan Peraturan Perundangundangan.

15 Tindakan hukum (rechtshandeling) didefinisikan sebagai perbuatan pemerintah yang termasuk dalam golongan perbuatan hukum atau berdasarkan sifatnya dapat menimbulkan akibat hukum tertentu. Lihat S.F. Marbun dan Moh. Mahfud MD., Pokok-Pokok Hukum Administrasi Negara, (Yogyakarta: Liberty, 2011), hlm. 68. Lihat juga Ridwan H.R., Hukum Administrasi Negara, Edisi Revisi, (Depok: Rajawali Pers, 2018), hlm. 109-110. 
jenis perbuatan pemerintah yang berdiri sendiri dan ditempatkan secara terpisah dari jenis pengelompokan perbuatan hukum pemerintahan. ${ }^{16}$ Pembedaan dari keduanya didasarkan pada ada atau tidaknya akibat hukum (rechtsgevolg). ${ }^{17}$ Namun demikian, tindakan faktual dapat saja menimbulkan akibat hukum, misalnya saja timbulnya kerugian terhadap warga negara sebagai akibat adanya upaya pembangunan yang dilakukan oleh pemerintah. ${ }^{18}$ Tindakan faktual atau feitelijk handeling tidak hanya terbatas pada tindakan aktif, namun juga tindakan pasif, yaitu pendiaman akan sesuatu hal. ${ }^{19}$ Tindakan Faktual atau feitelijk handeling akan selalu bersegi satu (eenzijdige) karena bersifat sepihak saja, oleh karenanya segala jenis feitelijk handelingen masuk ke dalam ranah hukum publik. ${ }^{20}$

Kedua, perluasan lingkup administrasi pemerintahan. Administrasi pemerintahan yang masuk dalam lingkup KTUN yang menjadi kompetensi absolut PTUN bukan saja pada lingkup eksekutif, tetapi diperluas, meliputi lingkup legislatif, yudikatif, dan penyelenggara negara lainnya dalam penyelenggaraan pemerintahan. Dengan demikian, obyek sengketa yang dapat digugat ke PTUN tidak hanya terbatas pada KTUN di lingkungan eksekutif saja, melainkan juga KTUN yang dikeluarkan oleh Badan atau Pejabat Tata Usaha Negara di cabang kekuasaan lain.

Ketiga, penambahan dasar dalam penerbitan KTUN. Pasca berlakunya UU Adpem, KTUN bukan hanya harus didasarkan pada peraturan perundang-undangan, namun harus pula didasarkan pada Asas-Asas Umum Pemerintahan yang Baik (AAUPB). Hal ini menjadi bersesuaian dengan praktik peradilan TUN yang selama ini telah berlangsung bahwa batu uji suatu KTUN ketika digugat di PTUN adalah kesesuaiannya dengan peraturan perundang-undangan yang berlaku asasasas umum pemerintahan yang baik. ${ }^{21}$ Namun demikian, AAUPB yang diatur dalam UU Adpem lebih meluas bila dibandingkan dengan UU Peratun 1986 dan perubahannya, yaitu seperti Tabel 3 pada halaman 373.

Berdasarkan tabel tersebut, dapat dilihat bahwa dinamika pengaturan mengenai AAUPB sebagai batu uji dalam menilai KTUN telah diperluas dalam UU Adpem, bukan hanya sebagaimana tertuang dalam UU Peratun 1986 dan perubahannya, serta UU Nomor 28 Tahun 1999 tentang Penyelenggara Negara yang Bersih dan Bebas dari Korupsi, Kolusi, dan Nepotisme, tetapi bahkan membuka peluang asas-asas lain di luar AAUPB sepanjang asas tersebut tertuang dalam putusan pengadilan yang berkekuatan hukum tetap.

Philipus M. Hadjon, dkk, op.cit., hlm. 170.

Ibid., hlm. 171.

Ibid., hlm. 172.

19 Safri Nugraha, dkk, Hukum Administrasi Negara (Depok: Badan Penerbit Fakultas Hukum Universitas Indonesia, 2007), hlm. 85. Lihat juga Muhammad Adiguna Bimasakti, "Batasan Tindakan dalam Hukum Administrasi Pemerintahan dan Perbuatan dalam Hukum Perdata oleh Pemerintah", Pengadilan Tata Usaha Negara Makassar, http://ptun-makassar.go.id/batasan-tindakan-dalam-hukum-administrasi-pemerintahan-dan-perbuatandalam-hukum-perdata-oleh-pemerintah (diakses 20 Agustus 2020).

20 Ibid.

21 Pasal 53 ayat (2) Undang-Undang Nomor 9 Tahun 2004 tentang Perubahan Atas Undang-Undang Nomor 5 Tahun 1986 tentang Peradilan Tata Usaha Negara. Lihat juga Francisca Romana Harjiyatni dan Suswoto, "Implikasi Undang-Undang Nomor 30 Tahun 2014 tentang Administrasi Pemerintahan terhadap Fungsi Peradilan Tata Usaha Negara", Jurnal Hukum Ius Quia Iustum, Vol. 24, No. 4 (2017): 611. 
Tabel 3. Asas-Asas Umum Pemerintahan yang Baik dalam UU Peratun dan UU Adpem

\begin{tabular}{|c|c|}
\hline UU Peratun 1986 dan perubahannya ${ }^{22}$ & UU Adpem ${ }^{23}$ \\
\hline $\begin{array}{l}\text { Yang dimaksud dengan "asas-asas umum } \\
\text { pemerintahan yang baik" adalah meliputi } \\
\text { asas: } \\
\text { - kepastian hukum; } \\
\text { - tertib penyelenggaraan } \\
\text { negara; } \\
\text { - keterbukaan; } \\
\text { - proporsionalitas; } \\
\text { - profesionalitas; } \\
\text { - } \text { akuntabilitas, }\end{array}$ & $\begin{array}{l}\text { (1) AUPB yang dimaksud dalam Undang-Undang ini meliputi } \\
\text { asas: } \\
\text { a. kepastian hukum; } \\
\text { b. kemanfaatan; } \\
\text { c. ketidakberpihakan; } \\
\text { d. kecermatan; } \\
\text { e. tidak menyalahgunakan kewenangan; } \\
\text { f. keterbukaan; } \\
\text { g. kepentingan umum; dan } \\
\text { h. pelayanan yang baik. }\end{array}$ \\
\hline $\begin{array}{l}\text { sebagaimana dimaksud dalam Undang- } \\
\text { Undang Nomor } 28 \text { Tahun } 1999 \text { tentang } \\
\text { Penyelenggara Negara yang Bersih dan } \\
\text { Bebas dari Korupsi, Kolusi, dan Nepotisme. }\end{array}$ & $\begin{array}{l}\text { (2) Asas-asas umum lainnya di luar AUPB sebagaimana } \\
\text { dimaksud pada ayat (1) dapat diterapkan sepanjang } \\
\text { dijadikan dasar penilaian hakim yang tertuang dalam } \\
\text { putusan Pengadilan yang berkekuatan hukum tetap. }\end{array}$ \\
\hline
\end{tabular}

Sumber: Diolah Penulis, 2020.

Hal ini berarti UU Adpem mencoba menggiring hakim PTUN untuk menerapkan yurisprudensi berdasarkan putusan-putusan sebelumnya sepanjang telah mempunyai kekuatan hukum tetap (inkracht van gewijsde), namun anehnya justru asas-asas umum lainnya di luar AUPB dijelaskan dalam UU Adpem sebagai asas umum pemerintahan yang baik yang bersumber dari putusan pengadilan negeri yang tidak dibanding, atau putusan pengadilan tinggi yang tidak dikasasi atau putusan Mahkamah Agung. ${ }^{24} \mathrm{Hal}$ ini tentu menjadi pertanyaan lebih lanjut, mengapa perkara dalam peradilan TUN justru merujuk pada putusan pada peradilan umum?
Keempat, perubahan sifat KTUN. Bila dalam UU Peratun 1986 dan perubahannya sifat dari KTUN adalah konkret, individual, dan final, maka dengan diundangkannya UU Adpem, sifat KTUN berubah menjadi final dalam arti lebih luas, yaitu mencakup Keputusan yang diambil alih oleh Atasan Pejabat yang berwenang. ${ }^{25}$ Rumusan penjelasan a quo sejatinya tidak memberikan kejelasan ${ }^{26}$ dan menimbulkan pertanyaan: (a) apakah KTUN tidak lagi bersifat konkret dan individual? dan (b) apakah KTUN hanya bersifat final dalam arti luas? Pertanyaan tersebut relevan untuk dipertanyakan karena rumusan Pasal 87 UU Adpem secara mutatis mutandis mengubah

22 Penjelasan Pasal 53 ayat (2) Undang-Undang Nomor 9 Tahun 2004 tentang Perubahan Atas Undang-Undang Nomor 5 Tahun 1986 tentang Peradilan Tata Usaha Negara.

23 Pasal 10 Undang-Undang Nomor 30 Tahun 2014 tentang Administrasi Pemerintahan.

24 Penjelasan Pasal 10 ayat (2) Undang-Undang Nomor 30 Tahun 2014 tentang Administrasi Pemerintahan.

25 Penjelasan Pasal 87 huruf d Undang-Undang Nomor 30 Tahun 2014 tentang Administrasi Pemerintahan.

26 Bandingkan dengan Philipus M. Hadjon, "Peradilan Tata Usaha Negara dalam Konteks Undang-Undang No. 30 Tahun 2014 tentang Administrasi Pemerintahan", Jurnal Hukum dan Peradilan, Vol. 4, No. 1 (2015): 55. Lihat juga Aju Putrijanti, "Kewenangan Serta Obyek Sengketa di Peradilan Tata Usaha Negara Setelah Ada UU No. 30/2014 tentang Administrasi Pemerintahan", Masalah-Masalah Hukum, Vol. 44, No. 4 (2015): 429. 
cara membaca definisi KTUN dalam UU Peratun 1986 dan perubahannya.

Selain dinamika pengaturan KTUN di atas, terdapat pengaturan lain terkait KTUN yang turut memberikan andil dalam memperluas atau mempersempit kompetensi absolut PTUN, yaitu pengaturan mengenai pembatasan KTUN yang dapat diadili oleh PTUN. UU Peratun 1986 dan perubahannya mengatur bahwa KTUN berikut ini tidak termasuk dalam pengertian KTUN yang dapat diadili oleh PTUN, yaitu: ${ }^{27}$

a. Keputusan Tata Usaha Negara yang merupakan perbuatan hukum perdata;

b. Keputusan Tata Usaha Negara yang merupakan pengaturan yang bersifat umum;

c. Keputusan Tata Usaha Negara yang masih memerlukan persetujuan;

d. Keputusan Tata Usaha Negara yang dikeluarkan berdasarkan ketentuan Kitab Undang-Undang Hukum Pidana dan Kitab Undang-Undang Hukum Acara Pidana atau peraturan perundang-undangan lain yang bersifat hukum pidana;

e. Keputusan Tata Usaha Negara yang dikeluarkan atas dasar hasil pemeriksaan badan peradilan berdasarkan ketentuan peraturan perundang-undangan yang berlaku;

f. Keputusan Tata Usaha Negara mengenai tata usaha Tentara Nasional Indonesia; g. Keputusan Komisi Pemilihan Umum baik di pusat maupun di daerah mengenai hasil pemilihan umum.

Selain itu, PTUN juga tidak berwenang memeriksa, memutus, dan menyelesaikan sengketa Tata Usaha Negara tertentu dalam hal keputusan yang disengketakan itu dikeluarkan: (a) dalam waktu perang, keadaan bahaya, keadaan bencana alam, atau keadaan luar biasa yang membahayakan, berdasarkan peraturan perundang-undangan yang berlaku; dan (b) dalam keadaan mendesak untuk kepentingan umum berdasarkan peraturan perundang-undangan yang berlaku. ${ }^{28}$

Kedua ketentuan a quo dalam konteks konseptual disebut sebagai pembatasan langsung terhadap kompetensi absolut PTUN. ${ }^{29}$ Selain itu, juga dikenal adanya pembatasan tidak langsung atas kompetensi absolut PTUN, yaitu PTUN baru berwenang memeriksa, memutus, dan menyelesaikan sengketa TUN jika seluruh upaya administratif yang bersangkutan telah digunakan, dalam hal suatu Badan atau Pejabat Tata Usaha Negara diberi wewenang oleh atau berdasarkan peraturan perundang-undangan untuk menyelesaikan secara administratif sengketa Tata Usaha Negara tertentu. ${ }^{30}$ Berdasarkan pembatasan tidak langsung tersebut, jika upaya administratif (administratief beroep) yang tersedia telah ditempuh dan pihak Penggugat masih dirugikan, ${ }^{31}$ maka 
Pengadilan Tinggi Tata Usaha Negara bertugas dan berwenang memeriksa, memutus, dan menyelesaikan di tingkat pertama sengketa Tata Usaha Negara tersebut. ${ }^{32}$

\section{Dikotomi Perbuatan Pemerintah dalam Pengadaan Barang/Jasa}

Menurut Utrecht, perbuatan pemerintah secara garis besar dapat dibedakan menjadi dua golongan, yaitu golongan perbuatan hukum (rechtshandelingen) dan golongan yang bukan perbuatan hukum (feitelijke handelingen). ${ }^{33}$ Spesifik terhadap perbuatan pemerintah yang termasuk golongan perbuatan hukum dibedakan lagi ke dalam dua golongan, yaitu perbuatan hukum menurut hukum privat (privaatrechtshandelingen) dan perbuatan hukum menurut hukum publik (publiekrechtshandelingen). ${ }^{34}$ Perbuatan hukum privat dalam hal ini diartikan sebagai perbuatan hukum yang dilakukan berdasarkan ketentuan hukum keperdataan, sedangkan perbuatan hukum publik berarti perbuatan hukum yang dilakukan berdasarkan hukum publik. ${ }^{35}$ Lebih lanjut, Hadjon menggunakan kriteria dasar dalam melakukan perbuatan hukum untuk membedakan keduanya, yaitu dalam perbuatan hukum privat, dasar untuk melakukan perbuatan hukum adalah adanya kecakapan (bekwaamheid) dari subjek hukum, ${ }^{36}$ sedangkan dalam perbuatan hukum publik dasar untuk melakukan perbuatan hukum adalah adanya kewenangan yang berkaitan dengan suatu jabatan $(a m b t) .{ }^{37}$

Sehubungan dengan konteks pengadaan barang/jasa, menjadi sukar untuk melakukan kategorisasi dari perbuatan pemerintah yang dilakukan dalam proses tersebut. Keterlibatan pemerintah dalam suatu hubungan kontraktual menjadikan hubungan kontraktual tersebut berbeda dengan kontrak komersial pada umumnya. ${ }^{38} \mathrm{Hal}$ ini mengingat bahwa dalam pengadaan barang/jasa, selain diatur oleh kaidah hukum privat, telah bercampur pula di dalamnya kaidah hukum publik (de gemengd publiek en privaatrechtelijke). ${ }^{39}$ Sebagai misal, dalam pengadaan barang/jasa, terdapat ketentuan peraturan perundang-undangan yang secara khusus mengatur prosedur yang harus ditempuh oleh badan atau pejabat tata usaha negara. ${ }^{40}$ Dengan kata lain, suatu badan atau pejabat tata usaha negara tidak dapat begitu saja melakukan pembelanjaan atau pengadaan barang/jasa bagi institusinya tanpa melalui tata cara maupun prosedur yang telah ditetapkan. ${ }^{41}$

Secara teoritis, salah satu cara untuk membedakan apakah suatu perbuatan

\footnotetext{
32 Pasal 51 ayat (3) Undang-Undang Nomor 5 Tahun 1986 tentang Peradilan Tata Usaha Negara.

33 E. Utrecht dalam S.F. Marbun dan Moh. Mahfud MD., Op.cit., hlm. 68.

Ibid. Lihat juga Ridwan H.R., Op.cit., hlm. 114.

Ibid., hlm. 115.

Philipus M. Hadjon, dkk, op.cit., hlm. 134.

37 Dengan perbedaan tersebut, tanggung gugat sehubungan dengan suatu perbuatan hukum publik adalah pada pejabat (ambtsdrager), sedangkan tanggung gugat dalam perbuatan hukum privat adalah pada badan hukum (publik). Lihat Ibid., hlm. 134-135.

38 Sarah S. Kuahaty, "Pemerintah sebagai Subjek Hukum Perdata dalam Kontrak Pengadaan Barang atau Jasa", Jurnal Sasi, Vol. 17, No. 3 (2011): 56.

39 Philipus M. Hadjon, dkk, Op.cit., hlm. 162. Lihat juga Ridwan H.R., loc.cit.

40 Pengaturan mengenai Pengadaan barang/jasa di Indonesia diatur dalam Peraturan Presiden Nomor 16 Tahun 2018 tentang Pengadaan Barang/Jasa Pemerintah. Lihat juga Philipus M. Hadjon, dkk, loc.cit.

41 Ibid.
} 
pemerintah merupakan perbuatan hukum publik atau perbuatan hukum privat adalah dengan melihat kedudukan pemerintah dalam melakukan perbuatan pemerintah tersebut. ${ }^{42}$ Apabila pemerintah bertindak dalam kapasitasnya sebagai pemerintah (pemegang kewenangan publik), maka perbuatan pemerintah tersebut adalah perbuatan hukum publik. ${ }^{43}$ Sebaliknya, apabila pemerintah bertindak dalam pergaulannya di bidang keperdataan, maka perbuatan pemerintah tersebut adalah termasuk dalam perbuatan hukum privat. ${ }^{44}$ Dalam konteks UU Peratun, KTUN dapat saja menjadi objek sengketa dari Peradilan TUN atau Peradilan Umum. Lingkungan peradilan mana yang kemudian berwenang untuk mengadili ditentukan dari apakah suatu KTUN tersebut dikualifikasikan sebagai KTUN yang merupakan perbuatan hukum perdata sebagaimana dimaksud dalam Pasal 2 huruf a UU Peratun atau bukan. ${ }^{45}$ Bilamana suatu KTUN dikualifikasikan sebagai KTUN yang merupakan perbuatan hukum perdata, maka menjadi kompetensi lingkungan peradilan umum. Sebaliknya, KTUN yang tidak masuk kualifikasi KTUN sebagaimana disebutkan dalam ketentuan Pasal 2 UU Peratun dan perubahannya menjadi kompetensi dari Peradilan TUN.

Berkaitan dengan hal tersebut, Indroharto mengemukakan apa yang disebut dengan teori melebur (oplossing theorie). Teori ini pada dasarnya meletakkan setiap KTUN yang diterbitkan dalam rangka menimbulkan hubungan kontraktual atau perjanjian melebur dalam perbuatan hukum perdata tersebut, sehingga kemudian yang berwenang mengadili dalam hal terdapat sengketa ialah peradilan umum. ${ }^{46}$ Secara lebih terperinci, KTUN yang dianggap melebur dalam perbuatan hukum perdata adalah sebagai berikut: ${ }^{47}$

1. Keputusan yang jangkauannya akan melahirkan atau justru menolak terjadinya suatu perbuatan hukum perdata;

2. Keputusan yang akan melebur dalam perbuatan hukum perdata;

3. Keputusan tata usaha negara yang menyebabkan dipenuhi tidaknya suatu syarat untuk dapat bekerjanya secara sah suatu tindakan menurut hukum perdata;

4. Keputusan tata usaha negara yang merupakan pelaksanaan dari suatu tindakan hukum perdata.

Namun demikian, pengertian dan kualifikasi sebagaimana dikemukakan Indroharto di atas sedemikian luasnya dan justru menutup kemungkinan akan adanya suatu KTUN yang diterbitkan dalam rangka menimbulkan hubungan kontraktual yang bukan merupakan perbuatan hukum perdata. Dalam hal ini perlu dilakukan penjernihan mengenai kriteria KTUN manakah yang kemudian dapat dikualifikasikan sebagai KTUN yang merupakan perbuatan hukum perdata dan mana yang dikualifikasikan sebagai KTUN

42 Ridwan H.R., loc.cit.

43 Ibid.

44 Ibid.

45 Lihat Pasal 2 huruf a Undang-Undang Nomor 5 Tahun 1986 tentang Peradilan Tata Usaha Negara sebagaimana diubah terakhir dengan Undang-Undang Nomor 51 Tahun 2009 tentang Perubahan Kedua Atas Undang-Undang Nomor 5 Tahun 1986 tentang Peradilan Tata Usaha Negara.

46 Indroharto, Usaha Memahami Undang-Undang tentang Peradilan Tata Usaha Negara - Buku I (Jakarta: Pustaka Sinar Harapan, 2004), hlm. 115-118.

47 Ibid., hlm. 117. 
yang bukan merupakan perbuatan hukum perdata, terkhusus dalam konteks proses pengadaan barang/jasa.

Dalam pelaksanaan pengadaan barang/ jasa melalui Penyedia, proses tender ditindaklanjuti dengan adanya penetapan dan hal ini barulah dapat dikatakan sebagai KTUN yang merupakan tindak lanjut dari perbuatan perdata, yaitu hasil lelang antara pemerintah sebagai pengguna barang/jasa dengan pelaku usaha selaku penyedia barang/jasa. ${ }^{50}$

Mendasarkan pada bagan di bawah ini,

Bagan 1. Tahapan Pengadaan Barang/Jasa Pemerintah Melalui Tender/Seleksi ${ }^{51}$

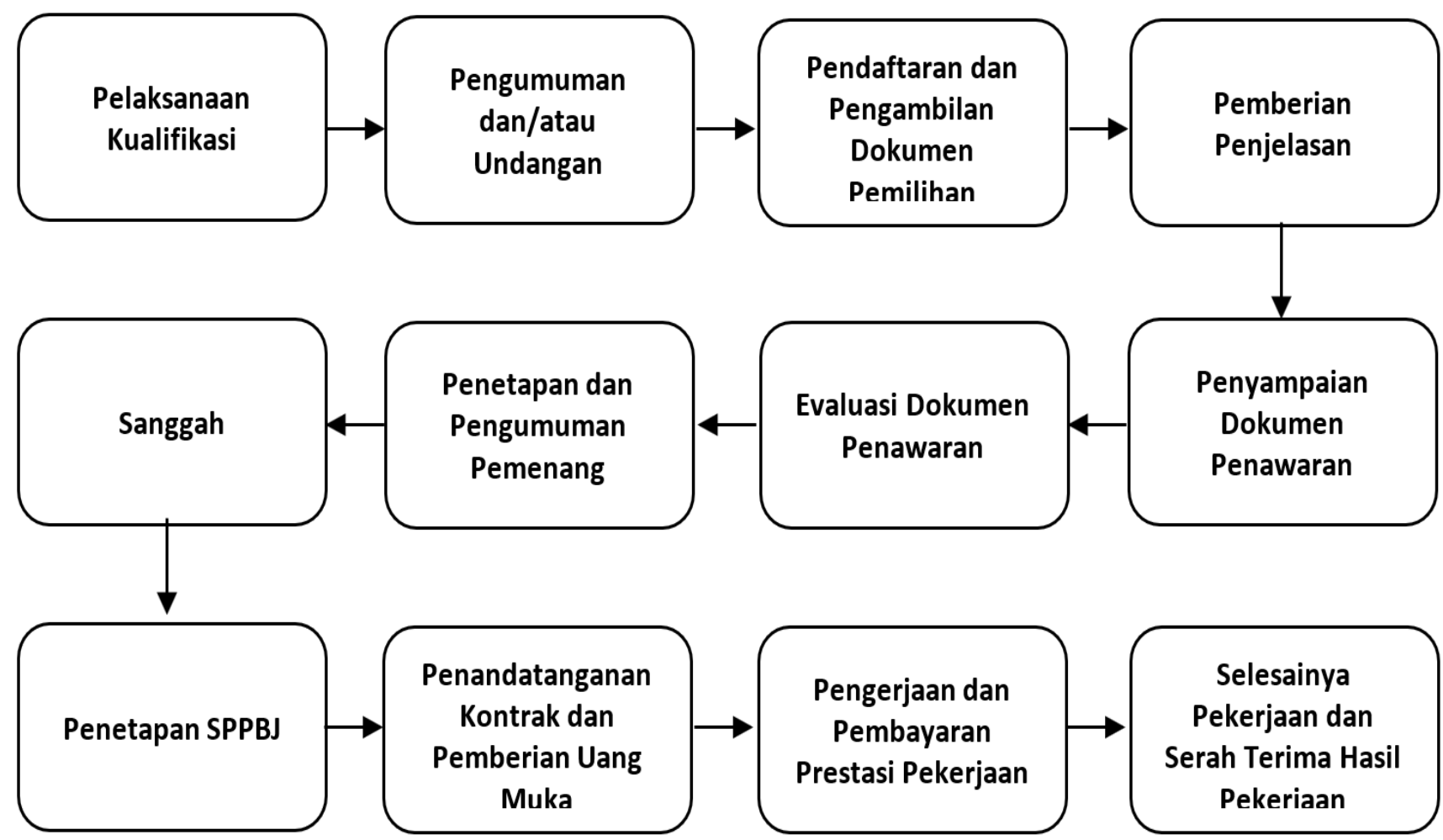

Sumber: Diolah Penulis, 2020.

pengumuman pemenang tender. ${ }^{48}$ Tergantung pada metode pemilihan dan nilai proyeknya, penetapan pemenang tersebut menjadi kewenangan Pengguna Anggaran atau Kelompok Kerja Pemilihan yang merupakan badan atau pejabat usaha negara. ${ }^{49}$ Penetapan pemenang lelang tersebut dalam menjadi penting untuk melihat secara lebih detail mengenai masing-masing tahapan dan dokumen apa yang dihasilkan dari masingmasing tahapan, sehingga kemudian dapat dikualifikasikan apakah dokumen tersebut adalah KTUN atau bukan. Penelusuran tersebut dapat dilihat pada tabel berikut:

48 Pasal 50 Peraturan Presiden Nomor 16 Tahun 2018 tentang Pengadaan Barang/Jasa Pemerintah.

49 Pasal 9 ayat (1) huruf n dan Pasal 13 ayat (1) huruf c Peraturan Presiden Nomor 16 Tahun 2018 tentang Pengadaan Barang/Jasa Pemerintah.

50 Febby Fajrurrahman, Op.cit., hlm. 201-202.

51 Pasal 50 dan 52 Peraturan Presiden Nomor 16 Tahun 2018 tentang Pengadaan Barang/Jasa Pemerintah. 
Tabel 4. Penelusuran Dokumen yang Dihasilkan dalam Proses Pengadaan Barang/Jasa Pemerintah Melalui Tender/Seleksi ${ }^{52}$

\begin{tabular}{|c|c|c|c|}
\hline No. & Tahapan & $\begin{array}{l}\text { Dokumen yang } \\
\text { Dihasilkan }\end{array}$ & Keterangan \\
\hline 1. & $\begin{array}{l}\text { Pelaksanaan } \\
\text { Kualifikasi }\end{array}$ & $\begin{array}{l}\text { Penetapan Hasil } \\
\text { Kualifikasi }\end{array}$ & $\begin{array}{l}\text { - Ditetapkan oleh Pokja Pemilihan. } \\
\text { - Didasarkan atas dipenuhinya persyaratan } \\
\text { administrasi/legalitas, teknis, dan keuangan oleh } \\
\text { Pelaku Usaha. }\end{array}$ \\
\hline 2. & $\begin{array}{l}\text { Pengumuman } \\
\text { dan/atau } \\
\text { Undangan }\end{array}$ & --- & $\begin{array}{l}\text { - Pengumuman dilakukan melalui aplikasi SPSE dan } \\
\text { dapat ditambahkan dalam situs web Kementerian/ } \\
\text { Lembaga/Pemerintah Daerah, papan pengumuman } \\
\text { resmi untuk masyarakat, surat kabar, dan/atau media } \\
\text { lainnya. } \\
\text { - Undangan tender/seleksi disampaikan oleh Pokja } \\
\text { Pemilihan. }\end{array}$ \\
\hline 3. & $\begin{array}{l}\text { Pendaftaran dan } \\
\text { Pengambilan } \\
\text { Dokumen } \\
\text { Pemilihan }\end{array}$ & --- & $\begin{array}{l}\text { Dilakukan oleh Pelaku Usaha yang diundang atau } \\
\text { berminat melalui aplikasi SPSE. }\end{array}$ \\
\hline 4. & $\begin{array}{l}\text { Pemberian } \\
\text { Penjelasan }\end{array}$ & $\begin{array}{l}\text { Berita Acara Hasil } \\
\text { Pemberian Penjelasan }\end{array}$ & $\begin{array}{l}\text { - Dilakukan oleh Pokja Pemilihan melalui aplikasi SPSE } \\
\text { sesuai jadwal yang telah ditetapkan. } \\
\text { - Berita Acara Hasil Pemberian Penjelasan dibuat } \\
\text { oleh Pokja Pemilihan. }\end{array}$ \\
\hline 5. & $\begin{array}{l}\text { Penyampaian } \\
\text { Dokumen } \\
\text { Penawaran }\end{array}$ & $\begin{array}{l}\text { Berita Acara Pembukaan } \\
\text { Penawaran }\end{array}$ & $\begin{array}{l}\text { - Metode penyampaian ditetapkan oleh Pokja } \\
\text { Pemilihan dengan memperhatikan jenis pengadaan } \\
\text { barang/jasa, metode pemilihan Penyedia, metode } \\
\text { evaluasi penawaran, dan ruang lingkup/kompleksitas } \\
\text { pekerjaan. } \\
\text { - Dokumen penawaran disampaikan oleh peserta } \\
\text { pemilihan sesuai ketentuan yang telah ditetapkan } \\
\text { dalam Dokumen Tender/Seleksi. } \\
\text { - Berita Acara Pembukaan Penawaran dibuat oleh } \\
\text { Pokja Pemilihan. }\end{array}$ \\
\hline 6. & $\begin{array}{l}\text { Evaluasi } \\
\text { Dokumen } \\
\text { Penawaran }\end{array}$ & $\begin{array}{l}\text { Berita Acara Evaluasi } \\
\text { Dokumen Penawaran }\end{array}$ & $\begin{array}{l}\text { Dilakukan oleh Pokja Pemilihan dengan metode } \\
\text { evaluasi sistem nilai, penilaian biaya selama umur } \\
\text { ekonomis atau harga terendah. }\end{array}$ \\
\hline
\end{tabular}

52 Lampiran Peraturan Lembaga Kebijakan Pengadaan Barang/Jasa Pemerintah Nomor 9 Tahun 2018 tentang Pedoman Pelaksanaan Pengadaan Barang/Jasa Melalui Penyedia. 


\begin{tabular}{|c|c|c|c|}
\hline No. & Tahapan & $\begin{array}{l}\text { Dokumen yang } \\
\text { Dihasilkan }\end{array}$ & Keterangan \\
\hline 7. & $\begin{array}{l}\text { Penetapan dan } \\
\text { Pengumuman } \\
\text { Pemenang } \\
\text { Lelang }\end{array}$ & $\begin{array}{l}\text { - } \text { Berita Acara Hasil } \\
\text { Pemilihan (BAHP) } \\
\text { - Penetapan Calon } \\
\text { Pemenang Lelang } \\
\text { - Penetapan Pemenang } \\
\text { Lelang }\end{array}$ & $\begin{array}{l}\text { - BAHP dibuat oleh Pokja Pemilihan. } \\
\text { - Penetapan calon pemenang ditetapkan oleh Pokja } \\
\text { Pemilihan berdasarkan hasil evaluasi. } \\
\text { - Penetapan pemenang ditetapkan oleh Pokja } \\
\text { Pemilihan atau PA/KPA. } \\
\text { - Pengumuman pemenang lelang dilakukan oleh } \\
\text { Pokja Pemilihan melalui aplikasi SPSE. }\end{array}$ \\
\hline 8. & Sanggah & --- & $\begin{array}{l}\text { Merupakan protes dari peserta pemilihan yang } \\
\text { merasa dirugikan atas penetapan hasil pemilihan } \\
\text { Penyedia. }\end{array}$ \\
\hline 9. & Penetapan SPPBJ & $\begin{array}{l}\text { Surat Penunjukan } \\
\text { Penyedia Barang/Jasa }\end{array}$ & $\begin{array}{l}\text { Ditetapkan oleh Pejabat Penandatangan Kontrak } \\
\text { berdasarkan hasil reviu. }\end{array}$ \\
\hline 10. & $\begin{array}{l}\text { Penanda- } \\
\text { tanganan } \\
\text { Kontrak dan } \\
\text { Pemberian Uang } \\
\text { Muka }\end{array}$ & $\begin{array}{l}\text { Kontrak Pengadaan } \\
\text { Barang/Jasa }\end{array}$ & $\begin{array}{l}\text { - Ditandatangani oleh Pejabat Penandatangan } \\
\text { Kontrak dan Penyedia c.q. Direktur Utama/Pimpinan } \\
\text { Perusahaan/Pengurus Koperasi yang namanya } \\
\text { disebutkan dalam Anggaran Dasar. } \\
\text { - Pemberian uang muka dapat dimohonkan oleh } \\
\text { Penyedia kepada Pejabat Penandatanganan Kontrak } \\
\text { untuk melaksanakan pekerjaan sesuai Kontrak dan } \\
\text { rencana pengembaliannya. }\end{array}$ \\
\hline 11. & $\begin{array}{l}\text { Pengerjaan dan } \\
\text { Pembayaran } \\
\text { Prestasi } \\
\text { Pekerjaan }\end{array}$ & $\begin{array}{l}\text { - Surat Perintah Mulai } \\
\text { Kerja (SPMK) untuk } \\
\text { Pekerjaan Konstruksi/ } \\
\text { Jasa Lainnya/Jasa } \\
\text { Konsultansi } \\
\text { - Surat Perintah } \\
\text { Pengiriman (SPP) } \\
\text { untuk Barang }\end{array}$ & $\begin{array}{l}\text { - SPMK merupakan surat perintah dari Pejabat } \\
\text { Penandatangan Kontrak kepada Penyedia Pekerjaan } \\
\text { Konstruksi/Jasa Lainnya/Jasa Konsultansi untuk } \\
\text { segera memulai pelaksanaan pekerjaan sesuai } \\
\text { Kontrak. } \\
\text { - SPP merupakan surat perintah tertulis dari Pejabat } \\
\text { Penandatangan Kontrak kepada Penyedia Barang } \\
\text { untuk mulai melaksanakan pekerjaan penyediaan } \\
\text { barang sesuai Kontrak. } \\
\text { - Pembayaran prestasi pekerjaan dimohonkan secara } \\
\text { tertulis kepada Pejabat Penandatangan Kontrak } \\
\text { disertai laporan kemajuan/output pekerjaan sesuai } \\
\text { Kontrak. }\end{array}$ \\
\hline 12. & $\begin{array}{l}\text { Selesainya } \\
\text { Pekerjaan dan } \\
\text { Serah Terima } \\
\text { Hasil Pekerjaan }\end{array}$ & $\begin{array}{l}\text { Berita Acara Serah } \\
\text { Terima }\end{array}$ & $\begin{array}{l}\text { - Serah terima dilakukan setelah pekerjaan selesai } \\
100 \% \text { (seratus persen) dari Penyedia kepada Pejabat } \\
\text { Penandatangan Kontrak sampai dengan serah terima } \\
\text { hasil pekerjaan kepada PA/KPA. } \\
\text { - Berita Acara Serah Terima ditandatangani oleh } \\
\text { Pejabat Penandatangan Kontrak dan Penyedia. }\end{array}$ \\
\hline
\end{tabular}

Sumber: Diolah Penulis, 2020. 
Mendasarkan pada tabel di atas, dapat dilihat bahwa pada setiap tahapan dalam pengadaan barang/jasa menghasilkan dokumen yang dapat dicermati lebih lanjut apakah dokumen tersebut masuk dalam kualifikasi KTUN atau tidak. Pencermatan tersebut disajikan dalam tabel di bawah ini:

Tabel 5. Pencermatan Unsur KTUN dalam Dokumen yang Dihasilkan dalam Proses Pengadaan Barang/Jasa Pemerintah Melalui Tender/Seleksi

\section{Unsur KTUN}

\begin{tabular}{|c|c|c|c|c|c|}
\hline $\begin{array}{c}\text { Dokumen yang } \\
\text { Dihasilkan }\end{array}$ & $\begin{array}{c}\text { Bentuk } \\
\text { (penetapan } \\
\text { tertulis, } \\
\text { mencakup } \\
\text { juga tindakan } \\
\text { faktual) }\end{array}$ & $\begin{array}{c}\text { Pihak yang } \\
\text { Mengeluarkan } \\
\text { (Badan atau } \\
\text { Pejabat Tata } \\
\text { Usaha Negara) }\end{array}$ & $\begin{array}{c}\text { Dasar } \\
\text { (peraturan } \\
\text { perundang- } \\
\text { undangan } \\
\text { dan AUPB) }\end{array}$ & $\begin{array}{c}\text { Sifat } \\
\text { (final dalam } \\
\text { arti lebih luas, } \\
\text { berpotensi } \\
\text { menimbulkan } \\
\text { akibat } \\
\text { hukum) }\end{array}$ & $\begin{array}{c}\text { Adressat } \\
\text { (seseorang } \\
\text { atau badan } \\
\text { hukum) }\end{array}$ \\
\hline
\end{tabular}

\begin{tabular}{|c|c|c|c|c|c|}
\hline $\begin{array}{l}\text { Penetapan Hasil } \\
\text { Kualifikasi }\end{array}$ & $v$ & $\sqrt{ }$ & v & v & v \\
\hline $\begin{array}{l}\text { Berita Acara Hasil } \\
\text { Pemberian Penjelasan }\end{array}$ & $\checkmark$ & $\sqrt{ }$ & $\sqrt{ }$ & v & $\sqrt{ }$ \\
\hline $\begin{array}{l}\text { Berita Acara Pembukaan } \\
\text { Penawaran }\end{array}$ & $v$ & $\sqrt{ }$ & $\sqrt{ }$ & v & v \\
\hline $\begin{array}{l}\text { Berita Acara Evaluasi } \\
\text { Dokumen Penawaran }\end{array}$ & $\checkmark$ & $\checkmark$ & $v$ & v & $\sqrt{ }$ \\
\hline $\begin{array}{l}\text { Berita Acara Hasil } \\
\text { Pemilihan (BAHP) }\end{array}$ & $v$ & $\checkmark$ & $\sqrt{ }$ & v & $\checkmark$ \\
\hline $\begin{array}{l}\text { Penetapan Calon } \\
\text { Pemenang Lelang }\end{array}$ & $v$ & $\checkmark$ & $\sqrt{ }$ & $v$ & $\checkmark$ \\
\hline $\begin{array}{l}\text { Penetapan Pemenang } \\
\text { Lelang }\end{array}$ & 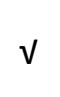 & $v$ & $\sqrt{ }$ & $v$ & $\sqrt{ }$ \\
\hline $\begin{array}{l}\text { Surat Penunjukan } \\
\text { Penyedia Barang/Jasa }\end{array}$ & $v$ & $\checkmark$ & v & v & $\checkmark$ \\
\hline $\begin{array}{l}\text { Kontrak Pengadaan } \\
\text { Barang/Jasa }\end{array}$ & --- & --- & $\sqrt{ }$ & $\checkmark$ & $\sqrt{ }$ \\
\hline $\begin{array}{l}\text { Surat Perintah Mulai Kerja } \\
\text { (SPMK) untuk Pekerjaan } \\
\text { Konstruksi/Jasa Lainnya/ } \\
\text { Jasa Konsultansi }\end{array}$ & $v$ & $\checkmark$ & $\sqrt{ }$ & $\checkmark$ & $\checkmark$ \\
\hline $\begin{array}{l}\text { Surat Perintah Pengiriman } \\
\text { (SPP) untuk Barang }\end{array}$ & $\checkmark$ & v & $\sqrt{ }$ & $\sqrt{ }$ & $\sqrt{ }$ \\
\hline Berita Acara Serah Terima & $v$ & v & $\sqrt{ }$ & $\sqrt{ }$ & $\mathrm{V}$ \\
\hline
\end{tabular}

Sumber: Diolah Penulis, 2020. 
Berdasarkan pada pencermatan unsur KTUN dalam dokumen yang dihasilkan dalam pengadaan barang/jasa dapat dilihat bahwa hanya 1 (satu) dokumen yang tidak memenuhi unsur KTUN karena tidak terpenuhinya unsur bentuk dan pihak yang mengeluarkan KTUN, yaitu Kontrak Pengadaan Barang/Jasa. Hal ini dikarenakan Kontrak Pengadaan Barang/Jasa ditandatangani oleh Pejabat Penandatangan Kontrak dan Penyedia c.q. Direktur Utama/ Pimpinan Perusahaan/Pengurus Koperasi yang namanya disebutkan dalam Anggaran Dasar. Kondisi ini membuat dokumen Kontrak Pengadaan Barang/Jasa bukanlah domain yang dapat serta merta dibuat oleh Badan atau Pejabat TUN. Selain itu, unsur bentuk dari KTUN berupa penetapan tertulis juga tidak dipenuhi, karena penetapan tertulis bukan semata terkait wujudnya yang harus tertulis, tetapi juga terkait sifat dari penetapan yang di dalamnya terdapat keleluasaan dari Badan atau Pejabat TUN untuk melakukan atau tidak melakukan, tanpa persetujuan kehendak dari pihak lain. ${ }^{53}$ Berbekal pemahaman kesesuaian antara dokumen yang dihasilkan dalam pengadaan barang/jasa dengan unsurunsur KTUN, selanjutnya perlu dilakukan penelaahan, apakah dokumen yang masuk dalam kualifikasi KTUN termasuk dalam KTUN yang dikecualikan dari kompetensi absolut PTUN.

\section{Menjernihkan Kompetensi Absolut Peradilan Tata Usaha Negara untuk Mengadili Perbuatan Pemerintah dalam Pengadaan Barang/Jasa}

KTUN yang dikecualikan dari kompetensi absolut PTUN dan terkait dengan pengadaan barang/jasa adalah KTUN yang merupakan perbuatan hukum perdata. Perlu dilakukan penelaahan apakah dokumen yang dihasilkan dalam pengadaan barang/jasa dan bersesuaian dengan unsur-unsur KTUN merupakan KTUN sebagai perbuatan hukum perdata? Untuk menjawab pertanyaan tersebut, perlu untuk dilihat bagaimana UU Peratun 1986 dan perubahannya mengatur mengenai KTUN yang merupakan perbuatan hukum perdata. Dalam UU Peratun 1986 dan perubahannya dijelaskan bahwa KTUN yang merupakan perbuatan hukum perdata, misalnya keputusan yang menyangkut masalah jual beli yang dilakukan antara instansi pemerintah dan perseorangan yang didasarkan pada ketentuan hukum perdata. ${ }^{54}$

Berdasarkan rumusan penjelasan a quo, walaupun penjelasan bukanlah norma, ${ }^{55}$ namun bila ditafsirkan secara gramatikal, ${ }^{56}$

53 Soehardjo, Hukum Administrasi Negara: Pokok-Pokok Pengertian serta Perkembangannya di Indonesia (Semarang: Badan Penerbit Universitas Diponegoro, 1991), hlm. 41-42. Lihat juga Kamarullah, Keputusan Tata Usaha Negara yang Merupakan Perbuatan Hukum Perdata Berdasarkan Ketentuan Pasal 2 Butir a Undang-Undang Nomor 5 Tahun 1986 juncto Undang-Undang Nomor 9 Tahun 2004 tentang Perubahan Atas Undang-Undang Nomor 5 Tahun 1986 tentang Peradilan Tata Usaha Negara (Surabaya: Disertasi Program Pascasarjana Universitas Airlangga, 2008), hlm. 92.

54 Penjelasan Pasal 2 huruf a Undang-Undang Nomor 9 Tahun 2004 tentang Perubahan Atas Undang-Undang Nomor 5 Tahun 1986 tentang Peradilan Tata Usaha Negara.

55 Lampiran II Angka 177 Undang-Undang Nomor 11 Tahun 2012 tentang Pembentukan Peraturan Perundangundangan.

56 Penafsiran yang menekankan pada makna teks yang di dalamnya kaidah hukum dinyatakan, bertolak dari makna menurut pemakaian bahasa sehari-hari atau makna teknis-yuridis yang lazim atau dianggap sudah baku. Lazim digunakan negara yang menganut tertib hukum kodifikasi, karena teks harfiah undang-undang sangat penting. 
rumusan penjelasan a quo dapat dimaknai bahwa KTUN yang merupakan perbuatan hukum perdata adalah KTUN yang diterbitkan dengan didasari dari adanya suatu perbuatan hukum yang didasarkan pada ketentuan hukum perdata terlebih dahulu. Pemikiran ini sejalan dengan hasil penelitian disertasi Kamarullah, yang mengkritisi pendapat Indroharto yang memperluas makna KTUN yang merupakan perbuatan hukum perdata sebagai keputusan yang jangkauannya melahirkan suatu perbuatan hukum perdata. ${ }^{57}$ Merujuk pada Kamarullah, seharusnya KTUN yang merupakan perbuatan hukum perdata mengandung unsur: (a) suatu keputusan yang semata-mata dikeluarkan atas dasar perjanjian yang dibuat; (b) sebagai hubungan hukum para pihak; dan (c) berlaku syarat dan ketentuan-ketentuan perjanjian dalam hukum perdata. ${ }^{58}$

Maknanya KTUN bersifat ex post dari suatu perbuatan perdata, bukan bersifat ex ante dari suatu perbuatan perdata. Bila penafsiran ini digunakan untuk memaknai rumusan penjelasan a quo, maka mutatis mutandis dokumen yang dihasilkan dalam pengadaan barang/jasa yang dikualifikasikan sebagai KTUN yang merupakan perbuatan hukum perdata adalah dokumen-dokumen yang terbit pasca dibuatnya Kontrak Pengadaan Barang/Jasa. Hal ini menjadikan dokumen yang dihasilkan dalam pengadaan barang/ jasa sebelumnya terbitnya Kontrak Pengadaan Barang/Jasa harus dimaknai sebagai KTUN yang menjadi kompetensi absolut PTUN.
Namun demikian, dalam praktik memang terdapat diskursus mengenai KTUN yang merupakan perbuatan hukum perdata. Salah satu putusan yang paling banyak dirujuk oleh hakim TUN dalam memutus gugatan dengan obyek KTUN yang dinilai sebagai perbuatan hukum perdata adalah Putusan Mahkamah Agung Nomor 252K/TUN/2000, tertanggal 13 November 2000, sebagai putusan kasasi atas Putusan Pengadilan Tinggi Tata Usaha Negara Surabaya Nomor 27/B/TUN/2000/PT.TUN.SBY jo. Putusan Pengadilan Tata Usaha Negara Surabaya Nomor 137/G.TUN/1999/PTUN. SBY, dengan obyek gugatan berupa Surat Keputusan Dirut PDAB tentang Pembatalan/ Pemutusan Hubungan Kerja Sama Proyek Air Bersih Umbulan, yang didasarkan atas Surat Gubernur Kepala Daerah Tk. I Provinsi Jawa Timur Nomor 690/6685/022/1999, tertanggal 30 Juni 1999, yang pada pokoknya berisi persetujuan pemutusan hubungan kerja sama proyek air bersih Umbulan antara PT. Citra Mandala Umbulan dengan Dirut PDAB Provinsi Jawa Timur.

Dalam Putusan a quo, Majelis Kasasi memberikan pertimbangan hukum: ${ }^{59}$

[...] segala keputusan tata usaha negara yang diterbitkan dalam rangka untuk menimbulkan perjanjian a quo, maupun diterbitkan dalam kaitannya dengan pelaksanaan isi bunyi perjanjian itu an sich, ataupun merujuk pada suatu ketentuan dalam perjanjian (kontrak) yang menjadi dasar hubungan hukum antara kedua belah pihak, haruslah dianggap melebur (oplossing) ke dalam hukum perdata, dan karenanya merupakan keputusan tata

B. Arief Sidharta, Penemuan Hukum, (Bandung: Laboratorium Hukum FH Universitas Parahyangan, 2001), hlm. 25. Lihat juga Afif Khalid, "Penafsiran Hukum oleh Hakim dalam Sistem Peradilan di Indonesia", Al 'Adl, Vol. VI, No. 11 (2014): 12.

57 Indroharto, Op.cit., hlm. 117.

58 Kamarullah, Op.cit., hlm. 154.

59 Putusan Mahkamah Agung Nomor 252K/TUN/2000, tertanggal 13 November 2000. 
usaha negara dalam arti pasal 2 huruf a Undang-Undang Nomor 5 Tahun 1986 [...].

Bila dicermati pertimbangan hukum a quo sejalan dengan pemikiran Indroharto yang memberikan penafsiran ekstensif terhadap ketentuan mengenai KTUN yang merupakan perbuatan hukum perdata, sehingga walaupun perbuatan hukum perdata tersebut belum secara riil terjadi, namun KTUN yang dikeluarkan dinilai merupakan perbuatan hukum perdata. Pandangan ini walaupun diikuti oleh banyak hakim TUN dalam memutus perkara, namun sejatinya memiliki kelemahan logika hukum dalam mendudukkan KTUN sebagai perbuatan perdata, padahal perbuatan perdata yang dimaksud belum secara faktual eksis.

Dalam konteks pengadaan barang/jasa pemerintah, sebagaimana penelusuran kesesuaian antara dokumen yang dihasilkan dalam pengadaan barang/jasa dengan unsurunsur KTUN, dapat dilihat bahwa perbuatan hukum perdata baru lahir ketika dokumen Kontrak Pengadaan Barang/Jasa dibuat, dengan demikian mutatis mutandis KTUN yang dapat dikualifikasikan sebagai perbuatan hukum perdata adalah KTUN yang lahir pasca dibuatnya dokumen Kontrak Pengadaan Barang/Jasa, dan bukan KTUN yang terbit sebelum dokumen Kontrak Pengadaan Barang/Jasa dibuat.

Pemahaman di atas dalam praktik peradilan TUN di Indonesia mulai digunakan dan menggeser pertimbangan hukum dalam Putusan Mahkamah Agung Nomor 252K/TUN/2000, misalnya dalam Putusan Mahkamah Agung Nomor 557K/TUN/2014 yang menguatkan Putusan Pengadilan Tinggi Tata Usaha Negara Jakarta Nomor 11/G/2014/
PT.TUN.JKT, yang menyatakan bahwasanya obyek gugatan berupa Keputusan Kepala Korps Lalu Lintas Kepolisian Republik Indonesia Nomor Kep/20/III/2014 tentang Penetapan Pemenang Pengadaan Bahan Baku TNKB Korlantas Polri TA 2014, tanggal 27 Maret 2014, telah memenuhi kualifikasi sebagai KTUN dan bukan termasuk KTUN yang merupakan perbuatan hukum perdata sebagaimana dimaksud dalam Pasal 2 huruf a UU Peratun 1986 dan perubahannya, yaitu: ${ }^{60}$

[...] karena kewenangan dalam menetapkan sebagai pemenang pengadaan barang/jasa tersebut sepenuhnya ada pada Tergugat I dan tidak didahului oleh Suatu perbuatan hukum perdata, meskipun pada akhirnya dengan suatu tahapan kontrak kerja dan sebagainya yang harus mengikuti rezim hukum perdata dan apabila dikemudian hari terhadap kesepakatan kontrak kerja tersebut timbul permasalahan hukum maka Kompetensinya adalah bukan lagi kewenangan Peradilan Tata Usaha Negara, melainkan Peradilan Perdata/ Umum [...] Penetapan Pemenang Lelang adalah Putusan pejabat Publik dan setelah penetapan pemenang lelang maka pemenang lelang baru melakukan perbuatan hukum perdata yaitu kontrak dengan Kuasa Pengguna Anggaran (KPA), sehingga kalau ada sengketa hukum mengenai pemenang lelang menjadi masalah hukum publik dan mengenai kontrak masuk ranah perdata. [...]

Alur pikir yang dipakai dalam Putusan $a$ quo adalah bila suatu KTUN didasarkan pada adanya suatu kewenangan (bevoegdheid) dan tidak didahului oleh suatu perbuatan hukum perdata, maka KTUN bukan merupakan perbuatan hukum perdata sebagaimana dimaksud dalam Pasal 2 huruf a UU Peratun 1986 dan perubahannya. Logika ini sejalan dengan penafsiran gramatikal di atas

60 Putusan Mahkamah Agung Nomor 557K/TUN/2014, tertanggal 6 Oktober 2014. 
bahwa memang seharusnya KTUN yang dikualifikasikan sebagai perbuatan hukum perdata adalah KTUN yang didasarkan pada perbuatan hukum perdata. Dengan kata lain, harus terdapat perbuatan hukum perdata terlebih dahulu sebelum KTUN diterbitkan.

\section{Penutup}

Berdasarkan analisis dan uraian di atas, dapat disimpulkan sebagai berikut: Pertama, konstruksi hukum kompetensi absolut pengadilan tata usaha negara di Indonesia disandarkan pada adanya sengketa Tata Usaha Negara. Oleh karena itu, keberadaan Keputusan Tata Usaha Negara (KTUN) menjadi aspek vital dalam kompetensi absolut PTUN, karena dapat dikatakan sengketa TUN lahir karena adanya suatu KTUN.

Kedua, dikotomi perbuatan pemerintah dalam pengadaan barang/jasa dapat dilihat dari tahapan pengadaan barang/jasa, yaitu: (a) Pelaksanaan Kualifikasi; (b) Pengumuman dan/atau Undangan; (c) Pendaftaran dan Pengambilan Dokumen Pemilihan; (d) Pemberian Penjelasan; (e) Penyampaian Dokumen Penawaran; (f) Evaluasi Dokumen Penawaran; (g) Penetapan dan Pengumuman Pemenang Lelang; (g) Sanggah; (h) Penetapan SPPBJ; (i) Penandatanganan Kontrak dan Pemberian Uang Muka; (j) Pengerjaan dan Pembayaran Prestasi Pekerjaan; (k) Selesainya Pekerjaan dan Serah Terima Hasil Pekerjaan. Pada tahapan tersebut menghasilkan dokumen-dokumen yang notabene merupakan KTUN, kecuali dokumen Kontrak Pengadaan Barang/Jasa.

Ketiga, kompetensi absolut pengadilan tata usaha negara untuk mengadili perbuatan pemerintah dalam pengadaan barang/jasa dibatasi dengan ketentuan Pasal 2 huruf a UU
Peratun 1986 dan perubahannya, yaitu KTUN yang merupakan perbuatan hukum perdata. Namun demikian, sejatinya bila rumusan dalam UU Peratun 1986 dan perubahannya ditafsirkan menggunakan penafsiran gramatikal, expressis verbis dapat diketahui bahwa seharusnya KTUN yang dikualifikasikan sebagai perbuatan hukum perdata adalah KTUN yang lahir dengan didasarkan pada perbuatan hukum perdata yang telah eksis sebelum KTUN diterbitkan.

Mendasarkan pada kesimpulan di atas, sebaiknya mulai dipertimbangkan ulang mengenai bagaimana suatu KTUN yang merupakan perbuatan hukum perdata dimaknai. Tepatnya, sudah seharusnya ketentuan Pasal 2 huruf a Peradilan TUN dan perubahannya tidak ditafsirkan secara ekstensif, melainkan secara gramatikal dengan mengkualifikasikan KTUN yang lahir dengan didasarkan pada perbuatan hukum perdata sebagai KTUN yang merupakan perbuatan hukum perdata.

\section{Daftar Pustaka}

\section{Buku}

H.R., Ridwan, Hukum Administrasi Negara, Edisi Revisi (Depok: Rajawali Pers, 2018).

Hadjon, Philipus M., dkk, Pengantar Hukum Administrasi Indonesia (Yogyakarta: Gadjah Mada University Press, 2015).

Indroharto, Usaha Memahami Undang-Undang tentang Peradilan Tata Usaha Negara - Buku I (Jakarta: Pustaka Sinar Harapan, 2004).

Kamarullah, Keputusan Tata Usaha Negara yang Merupakan Perbuatan Hukum Perdata Berdasarkan Ketentuan Pasal 2 Butir a Undang-Undang Nomor 5 Tahun 1986 juncto Undang-Undang Nomor 9 Tahun 2004 tentang Perubahan Atas Undang-Undang Nomor 5 Tahun 1986 tentang Peradilan Tata Usaha Negara (Surabaya: Disertasi Program Pascasarjana Universitas Airlangga, 2008). 
Marbun, S.F., dan Moh. Mahfud MD., Pokok-Pokok Hukum Administrasi Negara (Yogyakarta: Liberty, 2011).

Marbun, S.F., Peradilan Administrasi Negara dan Upaya Administratif di Indonesia (Yogyakarta: UII Press, 2011).

Nugraha, Safri, dkk, Hukum Administrasi Negara (Depok: Badan Penerbit Fakultas Hukum Universitas Indonesia, 2007).

Sidharta, B. Arief, Penemuan Hukum (Bandung: Laboratorium Hukum FH Universitas Parahyangan, 2001).

Soehardjo, Hukum Administrasi Negara: PokokPokok Pengertian serta Perkembangannya di Indonesia (Semarang: Badan Penerbit Universitas Diponegoro, 1991).

Soekanto, Soedjono, dan Sri Mamudji, Penelitian Hukum Normatif: Suatu Tinjauan Singkat (Jakarta: Raja Grafindo Persada, 1994).

Soekanto, Soerdjono, Pengantar Penelitian Hukum (Jakarta: UI Press, 1986).

\section{Makalah/Artikel/Prosiding/Hasil Penelitian}

Effendi, Maftuh, "Peradilan Tata Usaha Negara Indonesia Suatu Pemikiran ke Arah Perluasan Kompetensi Pasca Amandemen Kedua UndangUndang Peradilan Tata Usaha Negara", Jurnal Hukum dan Peradilan, Vol. 3, No. 1 (2014).

Fajrurrahman, Febby, "Penerapan Hukum Pengadaan Barang/Jasa Pemerintah sebagai Sengketa Tata Usaha Negara", Jurnal Hukum Peratun, Vol. 2, No. 2 (2019).

H.R., Ridwan, Despan Heyansyah, dan Dian Kus Pratiwi, "Perluasan Kompetensi Absolut Pengadilan Tata Usaha Negara dalam UndangUndang Administrasi Pemerintahan", Jurnal Hukum Ius Quia lustum, Vol. 25, No. 2 (2018).

Hadjon, Philipus M., "Peradilan Tata Usaha Negara dalam Konteks Undang-Undang No. 30 Tahun 2014 tentang Administrasi Pemerintahan", Jurnal Hukum dan Peradilan, Vol. 4, No. 1 (2015).

Harjiyatni, Francisca Romana, dan Suswoto, "Implikasi Undang-Undang Nomor 30 Tahun 2014 tentang Administrasi Pemerintahan terhadap Fungsi Peradilan Tata Usaha Negara", Jurnal Hukum Ius Quia lustum, Vol. 24, No. 4 (2017).

Khalid, Afif, "Penafsiran Hukum oleh Hakim dalam Sistem Peradilan di Indonesia", Al 'Adl, Vol. VI, No. 11 (2014).
Kuahaty, Sarah S., "Pemerintah sebagai Subjek Hukum Perdata dalam Kontrak Pengadaan Barang atau Jasa", Jurnal Sasi, Vol. 17, No. 3 (2011).

Putrijanti, Aju, "Kewenangan Serta Obyek Sengketa di Peradilan Tata Usaha Negara Setelah Ada UU No. 30/2014 tentang Administrasi Pemerintahan", Masalah-Masalah Hukum, Vol. 44, No. 4 (2015).

Wahyunadi, Yodi Martono, "Disertasi Kompetensi Absolut Pengadilan Tata Usaha Negara dalam Konteks Undang-Undang Nomor 30 Tahun 2014 tentang Administrasi Pemerintahan", Jurnal Hukum dan Peradilan, Vol. 5, No. 1 (2016).

\section{Internet}

Abdullah, Ujang, "Kompetensi Peradilan Tata Usaha Negara dalam Sistem Peradilan di Indonesia", Pengadilan Tata Usaha Negara Palembang, https://ptun-palembang.go.id/ upload_data/KOMPETENSI\%20PTUN.pdf (diakses 20 Agustus 2020).

Bimasakti, Muhammad Adiguna, "Batasan Tindakan dalam Hukum Administrasi Pemerintahan dan Perbuatan dalam Hukum Perdata oleh Pemerintah", Pengadilan Tata Usaha Negara Makassar, http:// ptun-makassar.go.id/batasan-tindakandalam-hukum-administrasi-pemerintahandan-perbuatan-dalam-hukum-perdata-olehpemerintah (diakses 20 Agustus 2020).

\section{Peraturan}

Undang-Undang Nomor 5 Tahun 1986 tentang Peradilan Tata Usaha Negara.

Undang-Undang Nomor 9 Tahun 2004 tentang Perubahan Atas Undang-Undang Nomor 5 Tahun 1986 tentang Peradilan Tata Usaha Negara.

Undang-Undang Nomor 51 Tahun 2009 tentang Perubahan Kedua Atas Undang-Undang Nomor 5 Tahun 1986 tentang Peradilan Tata Usaha Negara.

Undang-Undang Nomor 11 Tahun 2012 tentang Pembentukan Peraturan Perundangundangan.

Undang-Undang Nomor 30 Tahun 2014 tentang Administrasi Pemerintahan. 
Peraturan Presiden Nomor 16 Tahun 2018 tentang Pengadaan Barang/Jasa Pemerintah.

Peraturan Lembaga Kebijakan Pengadaan Barang/ Jasa Pemerintah Nomor 9 Tahun 2018 tentang Pedoman Pelaksanaan Pengadaan Barang/ Jasa Melalui Penyedia.

\section{Putusan Pengadilan}

Putusan Mahkamah Agung Nomor 252K/ TUN/2000, tertanggal 13 November 2000.

Putusan Mahkamah Agung Nomor 557K/ TUN/2014, tertanggal 6 Oktober 2014. 